\author{
Grzegorz Maciejewski \\ Uniwersytet Ekonomiczny w Katowicach
}

Sylwia Mokrysz

Mokate $S A$

\title{
NEW TRENDS IN CONSUMPTION ON THE COFFEE MARKET
}

The aim of the article is to present trends in consumption, which currently affect or will affect the behaviour of coffee consumers in the next 2-5 years. The article is written in the form of theoretical considerations supported by an analysis of source materials. It presents the main megatrends, consumer trends and product trends observed on the coffee market. It also describes relations between the aforementioned phenomena and consumer behaviour. The analysis of the collected data made it possible to conclude that the main trends determining consumer behaviour are naturalness and sustainability, health and nutrition, multisensory experience, convenience, digitalisation and individualisation. In order to meet these trends, producers and sellers of coffee will also want to gain an influence on the choices and preferences of coffee consumers by supporting and developing such product trends as: craft coffee time, the ice age is coming, ready to drink coffee, co-branding to dial up indulgence, convenient formats go premium, the rise of super coffee or the world of smart vending machines.

Keywords: megatrends, consumer trends, trends on the food and beverages market, product trends, coffee market

JEL Codes: D12, E21, M30

\section{Introduction}

The 21 st century has become the age of the consumer - an educated, conscious consumer, but also one that is impatient, disloyal and capricious ${ }^{1}$. Enterprises wishing to maintain or increase their competitiveness are forced to continuously and actively monitor changes in consumer behaviour, not only to keep up with buyers of their products, but to overtake them, creating a world in which consumers would like to live. The emerging megatrends and consumer trends are indicative of the expected future consumer behaviours.

The purpose of the article is to show new consumer trends and corresponding product trends in view of the identified megatrends, affecting the functioning of economies as well as entire societies. The article is written in the form of theoretical considerations supported by the analysis of data from secondary sources. The area of observations consists of entities operating on the coffee market.

This paper is organised as follows: the Theoretical Framework section defines the concepts of megatrends, consumer trends, product trends and the relationship between these concepts. Next, the Materials and Methods section presents the source materials used in the article and the method of their analysis. The Results and Discussion section begins with a

${ }^{1}$ G. Maciejewski: The Contemporary Consumer in the Face of Megatrends in Consumption [in:] OlejniczukMerta A. (ed.): The Transformation of Consumption and Consumer Behaviour, IBRKK, Warsaw 2012, p.29. 
short description of the coffee market. Then, this section presents a description of the most important current trends and megatrends combined with a discussion on the impact of the most dynamically developing product trends on purchasing behaviour and coffee consumption. The manuscript ends with conclusions made on the basis of the analysis carried out and a discussion of results. The conclusions from the presented material do not fully cover the subject, however, they can play a part in the discussion of observed changes taking place in consumer behaviour, as well as in $\mathrm{B} 2 \mathrm{C}$ relations. The data presented may also be useful for companies involved in the production and sale of coffee in the process of building their competitive advantage, based on permanent ties with consumers.

\section{Theoretical framework}

The concept of a trend has been present in reference materials since the mid-twentieth century, finding its place first in mathematical and economic sciences to describe changes in charts and sequences of numbers, and then in sociological or marketing sciences to describe changes in culture, worldviews or lifestyles ${ }^{2}$. Ph. Kotler describes a trend as "the direction or series of events characterised by a certain momentum and durability" ${ }^{3}$. B. Mróz defines the term 'trend' as "changes taking place over time in social or market phenomena, the direction of which can be measured by means of specific indicators, scales or indexes". ${ }^{4}$ In turn, T. Zalega, under the term 'trend', understands the direction of current development in a given field or, in a more general sense, the monotonic component of the given feature's dependence on time ${ }^{5}$. Trends can thus be short- or long-term in nature, and in regard to their range: can be global (megatrends) or regional (microtrends). The specific features of trends are volatility, coexistence (mutual overlap) and divergence (the simultaneous creation of trends and counter-trends).

$\mathrm{Ph}$. Kotler, referred to above, distinguishes between different trends on account of their durability, dividing them into temporary fashion, trends and megatrends. He describes temporary fashion as an unpredictable short-term change devoid of greater economic, social or political significance. Trends and megatrends, in the opinion of $\mathrm{Ph}$. Kotler, are more durable and easier to predict. A trend outlines the shape of the future, it is a long-term phenomenon, which can be observed in the behaviour of consumers and enterprises in many markets. The formation and development of a trend is confirmed by reliable values of economic, social and demographic indicators appearing at the same time $^{7}$. Megatrends, in turn, are unquestionably connected with globalisation ${ }^{8}$. According to J. Naisbitt, megatrends identify all socio-economic or structural processes that form

\footnotetext{
2 M. Raymond: The Trend Forecaster`s Handbook, Laurence King Publishing, London 2014, p. 14.

${ }^{3}$ Ph. Kotler: Marketing, Dom Wydawniczy Rebis, Poznań 2005, p. 159.

${ }^{4}$ B. Mróz: Konsument w globalnej gospodarce. Trzy perspektywy, Oficyna Wydawnicza SGH, Warsaw 2013, pp. 115-116.

${ }^{5}$ T. Zalega: Nowe trendy i makrotrendy w zachowaniach konsumenckich gospodarstw domowych w XXI wieku, Konsumpcja i Rozwój 2(5)/2013, pp. 3-4.

${ }^{6}$ J. Tkaczyk: Konsumpcja i konsument - nowe trendy. Handel Wewnętrzny, May - June 2012, pp. 126-127; S. Dybka: Trendy w zachowaniach konsumentów jako czynnik determinujący rozwój przedsiębiorstw, Studia Ekonomiczne. Zeszyty Naukowe Uniwersytetu Ekonomicznego w Katowicach 338/2017, p. 82.

${ }^{7}$ Ph. Kotler: Marketing, op.cit., p. 159.

${ }^{8}$ M. Maciaszczyk: Wybrane megatrendy i ich możliwy wpływ na konsumentów niepełnosprawnych ruchowo, Handel Wewnętrzny, 5(364)/2016, p.162.
} 
slowly, but when they do come into existence, have an impact on all areas of life for a certain time 9 . In addition, megatrends can have an impact on every person and can change and shape the future of the whole world ${ }^{10}$. The concept of a megatrend may also be defined as certain unchanging economic, social, political and cultural trends, as well as phenomena occurring in the process of the civilisational development of society, which has various conditions and embraces the whole planet, conditioning key goals and directions of human development ${ }^{11}$ that leave an imprint on the environment ${ }^{12}$. Megatrends thus identify sets of certain economic, social or environmental patterns of behaviour that change people's way of life as well as the products that these people need $^{13}$. Recalling the paper "The Impact of megatrends on western governments" by futurologist F. de Meyer, megatrends can be presented as long-lasting, fast-spreading trends that strongly influence society in many dimensions and evoke the conviction of their inevitability ${ }^{14}$.

The concept of a megatrend is close to the concept of a macrotrend, which H. Mruk defines as "objective, long-term directions of general consumer choices, behaviours and preferences" or as "significant social, economic, political and technological changes that form slowly, but when they come into existence, affect consumer behaviour for 7-10 years and even longer"15. The antonym of a macrotrend is a microtrend, the existence of which is indicated by B. Mróz referencing the work of M.J. Penn and E. Kinney Zalesne. The authors assume that it is not a few mega-forces that determine how the world works, but the multiple choices forming microtrends - small forces that can direct a small fraction of the population, as small as $1 \%$, but which nevertheless greatly shape entire societies ${ }^{16}$.

To fully show the role which trends play in consumer behaviour, it is worth referring to the views of H. Vejlgaard, who works in trend forecasting. This researcher defines a trend as a process of change, which is drawn from a psychological, economic or sociological perspective, which may be short- or long-term, and regional or global ${ }^{17}$. Taking this into consideration, it is possible to agree with $\mathrm{T}$. Zalega that "a trend in consumer behaviour is understood as a specific direction of change in the consumer's modelled lifestyle, acting in an objective way, independent of his will and consciousness" ${ }^{18}$. Looking at this issue from the

\footnotetext{
9 J. Pieriegud: Wykorzystanie megatrendów do analizy przyszłościowego rozwoju sektorów gospodarki, [in:] Gajewski J., Paprocki W., Pieriegud J., Megatrendy i ich wpływ na rozwój sektorów infrastrukturalnych, Instytut Badań nad Gospodarką Rynkową - Gdańska Akademia Bankowa, Gdańsk 2015, p.15.

${ }^{10}$ P. Zmyślony, A. Niezgoda: Popyt turystyczny. Uwarunkowania i perspektywy rozwoju, Wydawnictwo Akademii Ekonomicznej, Poznań 2003, p. 194.

11 S. Marek, M. Białasiewicz (ed.): Podstawy nauki o organizacji. Przedsiębiorstwo jako organizacja gospodarcza, PWE, Warsaw 2011, 389.

${ }^{12}$ K. Borodako: Foresight w zarzadzaniu strategicznym, C.H. Beck, Warsaw 2009, p.90.

${ }^{13}$ S. Hajkowicz, J. Moody: Our future world. An analysis of global trends, shocks and scenarios, CSIRO, Canberra 2010, p.2.

${ }^{14}$ F. de Meyer: The impact of megatrends on western governments, Institute for Future Insights, Available online: https://www.slideshare.net/fdemeyer/the-impact-of-megatrends-on-western-governments, (accessed on 09 February 2019); M. Maciaszczyk: Wybrane megatrendy ..., op. cit. p. 163.

${ }^{15}$ H. Mruk: Makrotrendy a zachowania konsumentów [in:] Kędzior Z. (ed.): Konsument. Gospodarstwo domowe. Rynek, CBiE Akademii Ekonomicznej w Katowicach, Katowice 2007, p.9.

${ }^{16}$ M.J. Penn, E. Kinney Zalesne: Mikrotrendy. Małe siły, które niosą wielkie zmiany, MT Biznes, Warsaw, p.13.

${ }^{17}$ H. Vejlgaard: Anatomy of trend, McGraw-Hill, New York 2008, p.9.

${ }^{18}$ T. Zalega: New consumer trends [in:] Burchard-Dziubińska M. (ed.), Towards a green economy. From ideas to practice, Wydawnictwo Uniwersytetu Łódzkiego, Łódź 2015, p. 80.
} 
perspective of $\mathrm{Ph}$. Kotler, it can be said that trends in the sphere of consumption arise as a result of influencing consumer purchasing behaviour in a broadly understood environment (social, economic, legal, political, demographic and technological), which, in turn, affects changes in their consumption patterns ${ }^{19}$.

According to F. Shaw, emerging consumer trends influence the way enterprises operate, thus creating new rules for the functioning of modern organisations ${ }^{20}$. The impact of new consumer trends on enterprises, therefore, results in changes in the behaviours of these entities, which on the one hand try to keep up with the changing consumer, and on the other hand start to shape consumer behaviour, preferences and choices. In the latter situation, we can speak about the creation of product trends by enterprises. Relations between megatrends, consumer trends, product trends and consumer behaviour are presented in Figure 1.

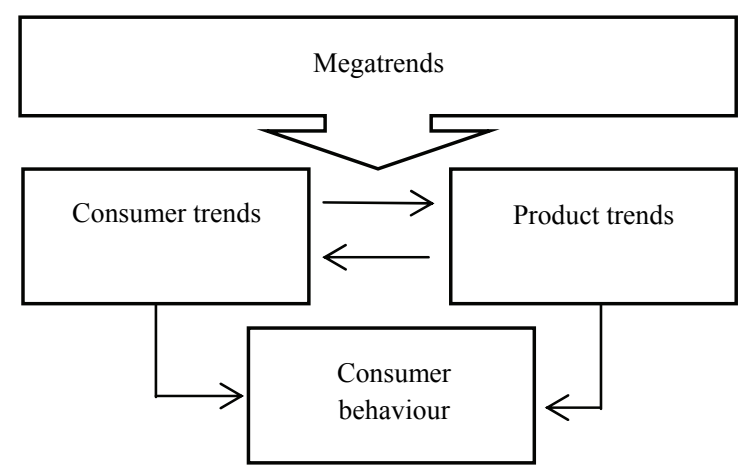

Figure 1. Relations between megatrends, consumer trends, product trends and consumer behaviour Source: Authors' own study.

\section{Materials and method}

The sources of the article include the results of research on consumer behaviour and the coffee market, conducted by renowned research agencies and consulting companies in 2015-2019.

First, research on megatrends, which are about to change the world over the next 20 years, carried out by the Ernst \& Young (EY) consulting company, is presented. The data presented by EY are the result of analyses based on reference materials and primary research carried out in renowned research centres from around the world ${ }^{21}$. Next, data from the Euromonitor International research agency is presented concerning the top 10 global consumer trends that could have the greatest impact on consumer behaviour in 2019 and subsequent years. The data were obtained as a result of direct quantitative research carried out in the autumn of 2018 by 14 regional company offices operating

\footnotetext{
${ }^{19} \mathrm{Ph}$. Kotler, G. Armstrong, J. Saunders, V. Wong: Marketing. Podręcznik europejski, PWE, Warsaw 2002, pp. $188-210$.

${ }^{20}$ F. Shaw: Uncertainty and the New Consumer, Foresight, 4/2009.

${ }^{21}$ Megatrends 2015. Making sense of a world in motion, EYGM Limited 2015, pp.52-53.
} 
globally ${ }^{22}$. Subsequently, information on product trends currently observed on the coffee market is presented. This data comes from the reports of the research agency Mintel Group Ltd. published in 2018-2019.

The data collected made it possible to create a profile of the entities operating in the coffee market and to analyse the impact of megatrends and new trends in consumption on consumer behaviour on the coffee market.

The research for the needs of this study was carried out using the desk research method, deductive inference and the comparative method were used for data analysis. The descriptive and tabular form was used to present the obtained research results.

\section{Results and discussion}

Megatrends affect consumer behaviour in the long run. EY, as the first of these trends, specifies the digital future (Table 1). In 2020, more than half of employees will belong to generations $\mathrm{Y}$ and $\mathrm{Z}$. These are generations that grew up along with the development of digital technologies. Modern technologies like the internet of things, artificial intelligence, robotics, augmented and virtual reality change the methods of work and employee involvement ${ }^{23}$. They also affect everyday life, mobility, forms of spending free time and travel. Digital technologies are beginning to be present in every sphere of human life, and their presence is more and more awaited and desired.

Table 1. Trends affecting consumer behaviour in the coffee market

\begin{tabular}{|c|c|c|c|}
\hline Megatrends & Consumer trends & $\begin{array}{c}\text { Consumer trends } \\
\text { on the food } \\
\text { and beverages market }\end{array}$ & $\begin{array}{l}\text { Product trends on the } \\
\text { coffee market }\end{array}$ \\
\hline $\begin{array}{ll}\text { 1. } & \text { Digital future } \\
\text { 2. } & \text { Entrepreneurship } \\
& \text { rising } \\
\text { 3. } & \text { Global } \\
& \text { marketplace } \\
\text { 4. } & \text { Urban world } \\
\text { 5. } & \text { Resource planet } \\
\text { 6. } & \text { Health reimagined }\end{array}$ & $\begin{array}{l}\text { 1. Digitally together } \\
\text { 2. Everyone is an } \\
\text { expert } \\
\text { 3. I want it now! } \\
\text { 4. Back to basics for } \\
\text { status } \\
\text { 5. Conscious } \\
\text { consumers } \\
\text { 6. Finding my } \\
\text { JOMO } \\
\text { 7. I want a plastic } \\
\text { free world } \\
\text { 8. We are ageless } \\
\text { 9. I can look after } \\
\text { myself } \\
\text { 10. Loner living }\end{array}$ & $\begin{array}{ll}\text { 1. } & \text { Naturalness and } \\
\text { 2. } & \text { Sustainability } \\
\text { 3. } & \text { Multh and nutrition } \\
& \text { experience } \\
\text { 4. } & \text { Convenience } \\
\text { 5. } & \text { Digitalisation } \\
\text { 6. } & \text { Individualisation }\end{array}$ & $\begin{array}{l}\text { 1. } \begin{array}{l}\text { Craft coffee time } \\
\text { 2. The ice age is } \\
\text { coming }\end{array} \\
\text { 3. } \begin{array}{l}\text { Ready to drink } \\
\text { coffee }\end{array} \\
\text { 4. lo-branding to dial } \\
\text { up indulgence } \\
\text { 5. Convenient formats } \\
\text { go premium } \\
\text { 6. Migration of single- } \\
\text { serve coffee } \\
\text { The rise of super } \\
\text { coffee } \\
\text { The world of smart } \\
\text { vending machines }\end{array}$ \\
\hline
\end{tabular}

Source: Authors' own research based on Megatrends 2015. Making sense of a world in motion, EYGM Limited 2015, pp.9-51; A. Angus, G. Westbrook: Top 10 global consumer trends 2019, Euromonitor International, London 2018, p.7-67; Consumer trends in food and beverages, Döhler Market Intelligence, Available online: http:/www.portalspozywczy.pl/handel/wiadomosci/d-hler-6-mega-trendow-konsumenckichksztaltuje-dzisiaj-rynek-zywnosci-i-napojow,146783.html, (accessed on 09 February 2019); J. Forsyth: Coffee 2018. Global Annual Review, Mintel Group Ltd., London 2018, pp.4-21.

${ }^{22}$ A. Angus, G. Westbrook: Top 10 global consumer trends 2019, Euromonitor International, London 2018, p. 69. ${ }^{23}$ New megatrends will transform the human experience and reshape markets, societies and the global order, EY, Press release, 11 June 2018. Available online: https://www.ey.com/en_gl/news/2018/06/new-megatrendswill-transform-the-human-experience-and-reshape,(accessed on 09 February 2019). 
Digitalisation creates almost unlimited possibilities of development, which supports the growing entrepreneurship, especially among young people. Currently, nearly $50 \%$ of entrepreneurs in the world are people between 25 and 44 years old. Importantly, growing entrepreneurship is also visible among women. EY estimates that 126 million women in the world have their own companies today, and about half of them employ workers.

Both of the megatrends support the development of another megatrend - a global marketplace. The differences between developed and fast developing countries will decrease. By 2030, rapidly developing countries will account for $47 \%$ of the global capital inflow, compared to $23 \%$ in 2010 . The middle class of Asian countries, especially China and India, will become the driving force ${ }^{24}$. Increasing mobility will make companies around the world fight for talented individuals - human capital to maintain their competitive advantage. The further development of globalisation will be opposed by the advocates of isolation and anti-globalists, forming a counter-trend to it. These phenomena will be particularly visible in culture and politics. Anti-globalisation activities will be supported by national, ethnic and religious movements.

Another megatrend, indicated by experts from EY, is urbanisation. The number of cities and the number of people living in cities is increasing worldwide. In $2015,54 \%$ of the world's population lived in cities. In $2050,66 \%$ will be living in them. People move to cities to take advantage of the economic benefits they provide to their residents. Therefore, it is becoming necessary to implement a sustainable development policy, especially in the area of transportation (railways, highways, airports), access to water and electricity.

Sustainable development is the source of the development of the next megatrend called the resource planet. By 2030, the world's population will have increased by 1.2 billion people, and the world's 750 largest cities will gain 220 million new middle-class consumers. This situation will increase the demand for raw materials and natural resources by $33 \%$. In 2035, annual electricity expenditure will reach $\$ 420$ billion. Mankind must start to use its raw materials and resources responsibly, not only because of the progressive degradation of the environment, but also due to the finite availability of non-renewable resources. Modern mining technologies and technologies that renew the environment are to help achieve these goals.

The last of the trends indicated by EY is health reimagined. Expenditure on health protection already absorbs $10 \%$ of global GDP. It is becoming necessary to find new solutions so as to reduce costs and meet the increasingly higher expectations and needs of people. To achieve this, a new perspective on health is necessary, a new definition of health. It is necessary to abandon the existing, traditional health care and go in the direction of health management, and thus towards prevention, shaping healthy habits and healthy eating.

Each of the described megatrends shapes the existing and emerging consumer trends to a greater or lesser extent $\mathrm{t}^{25}$. A. Angus and G. Westbrook have identified 10 new trends which influence consumer behaviour in 2019 and the subsequent years (Table 1).

\footnotetext{
24 M.A. Gonzalez-Perez, S. Gutierrez-Viana: Cooperation in coffee markets: The case of Vietnam and Colombia, Journal of Agribusiness in Developing and Emerging Economies 2(1)/2012, pp. 57-73.

25 D. Harrison: Ten global consumer trends in 2011, Strategic Direction 27(10)/2011, https://doi.org/10.1108/sd.2011.05627jaa.010.
} 
The first two: digital together and everyone is an expert are strongly associated with the digital future megatrend. Over the last decade, technology has evolved from facilitating communication to enabling multidimensional interactions and collective experiences. People at that time had to deal with the technological and regulatory barriers that are now being overcome. Now they use the internet, video calls and virtual platforms to meet and collaborate with people around the world in real time. In the real world they are separate - digitally, they are together. Digitalisation means unlimited possibilities for computer games enthusiasts, social networking sites or educational websites. From dating to education, from work to controlling your health - everything can be done digitally together. Consumers are increasingly using Twitter, WhatsApp or Instagram to advise each other about what and where to buy best, sharing discount coupons, informing each other about discounts and bargains. Thanks to modern technologies, everyone is an expert. Many consumers lead very fast lives, are busy and don't want to wait. From businesses, they expect goods and services to be delivered as quickly and as simply as possible. More and more of them use applications that help them organise their lives, avoid street traffic jams or shorten waiting times in the queue.

I want it now! - this is a trend followed by people living life in the fast lane, who do not want to waste time shopping and handling current affairs. B. Mróz calls this trend "immediate gratification" ${ }^{26}$. Many modern consumers do not want to wait, do not want to postpone consumption, do not want it "later" - they want it "now", "immediately". Determinants of the development of this trend should be sought in the global marketplace megatrend and the development of communication technologies conducive to the diffusion and imitation of lifestyles and consumption patterns.

On the other hand, the urban world and resourceful planet megatrends strongly affect several consumer trends, which can be considered as counter-trends to those discussed above. These include back to basics for status, conscious consumers, finding my JOMO (joy of missing out) or I want a plastic free world. More and more consumers are becoming conscious consumers. They understand that they did not inherit the Earth from their parents, but only borrowed it from their children. They are aware of their choices and responsibilities for the future of the world. They are moving away from greedy consumerism and turning toward simplicity, better quality, and uniqueness. They seek authentic, diverse products and experiences that allow them to express their individuality. This group of consumers is not indifferent to animal welfare and the state of the natural environment. These are consumers who do not have to have everything. They say "less is more", turning FOMO (fear of missing out) into JOMO.

The last three consumer trends mentioned by A. Angus and G. Westbrook are I can look after myself, loner living and we are ageless. The health reimagined megatrend is the foundation of their development. The boundaries of old age are constantly shifting. People live longer, care about their health, appearance and well-being. They continue to develop themselves even when they are 70 years old. Consumers following the 'I can look after myself' trend are focused on the prevention of diseases, obesity and everyday stress, shifting the boundary of old age further and further. These consumers use the advice of specialists in physical and mental health, applications that show them a healthy diet and products prepared especially for them. They want to feel special and self-

${ }^{26}$ B. Mróz: Konsument ..., op. cit., p. 163. 
sufficient. These consumers often also consciously reject marriage and even intercourse. They redefine lonely life into a lonely life that has been chosen. Reaching the age of 50+ years, they want to continue to enjoy the same things as their younger friends from the $\mathrm{Z}$ generation. They want products that will help them to keep their youthful body and spirit. They are often obsessed with new technologies, following the latest apps and smart devices. They do not think "we are old" about themselves, they think "we are ageless", "we are forever young!".

Connecting the megatrends and consumer trends which have been presented to the food and drink market, of which the coffee market is a part, attention should be paid primarily to six trends introduced by Döhler Market Intelligence (Table 1). The first of these is the naturalness and sustainability trend, which results from the development of health reimagined and resourceful planet megatrends and the related consumer trends. A growing need to return to what is natural and simple has been noticeable on the food and beverage market for a long time. Consumers expect full transparency of what they are being offered for consumption. They appreciate products based on the clean \& clear label formula, which means that the list of ingredients of products should be getting shorter and the information should be given in the most transparent way possible ${ }^{27}$. A contemporary consumer is an inquiring person who asks about the origin of the purchased product, its composition, production methods and, finally, the social responsibility of the producer $^{28}$.

There are also more and more consumers who treat food as a long-term investment in health and a youthful appearance. Nowadays, in almost every category of the food industry, new products can be found whose creators have focused on strengthening health-promoting properties. Therefore, the second trend which will have a strong impact on consumer behaviour on the food and beverage market, is the health and nutrition trend. Consumers expect food producers to implement the free from formula, i.e. elimination of unwanted ingredients from the recipe, such as sugar, gluten or lactose, or the addition of commonly expected ingredients such as vitamins, minerals, protein, plant extracts and superfoods.

The next indicated trend is the experience multisensory trend, having its genesis in the digital future megatrend. Consumers will increasingly pay attention to the special role of the sense of taste, smell or sight in the perception of the sensory quality of food products. Consumers want to experience food products with all their senses. Producers of food and drinks should look for innovation not only in terms of flavour, but also in the area of the product formula itself. Multisensory experiences cannot be achieved with one component. It is a combination of aroma, colour and texture. Consumers expect new products that use the combinations of various textures of ingredients, e.g. crunchy with creamy, or crunchy with liquidy.

Digitalisation also has a direct effect on the development of the food and drink market. In the era of the growing popularity of social media, the consumer co-creates the brand, which is why producers and sellers must skillfully use the available digital tools

\footnotetext{
${ }^{27}$ E. Dimara, D. Skuras: Consumer demand for informative labeling of quality food and drink products: a European Union case study, Journal of Consumer Marketing 22(2)/2005, p.90-100, https://doi.org/10.1108/07363760510589253.

${ }^{28}$ E. Papista, P. Chrysochou, A. Krystallis, S. Dimitriadis: Types of value and cost in consumer - green brands relationship and loyalty behaviour. Journal Consumer Behaviour 17/2018, p.101-113.
} 
in order to build and strengthen relationships with consumers. Consumers are becoming more and more comfort-loving and more focused on themselves and their needs. This situation is reflected in the last two trends - convenience and individualisation, whose beginnings can be found in the health reimagined megatrend and the I can look after myself, conscious consumers and I want it now! consumer trends. The contemporary consumer expects a convenient offer in the form of products fast and easy to prepare, and at the same time healthy, unique and tailored to individual needs. Mass production is losing interest. Today, everyone can easily find the "tailor-made", unique offer. What the consumer is looking for reflects his/her personality and lifestyle. Therefore, it should not be surprising that there will be an avalanche increase in consumer interest in craft beer or various craft products.

Consumers following the trends presented can also be seen on the coffee market. Consumers expect coffee that is easy to prepare, even ready for immediate consumption, high quality and yet affordable. Coffee which will stimulate you, but also improve the time spent at work or with friends. Coffee which entertains with its unusual combinations and intrigues with its original technological solutions ${ }^{29}$. Finally, coffee which improves the health condition of the person, and whose whole process of production and preparation takes place in accordance with the principles of sustainable development ${ }^{30}$. The actions of coffee producers and sellers responding to these expectations take the form of product trends.

The first thing to mention here is the very dynamic development of craft coffee and ready to drink coffee (RTD coffee) (Table 1.) Big coffee makers, but also chain coffee shops, invest in very good quality "craft" coffee. Their goal is to reach the more snobbish younger generation $\mathrm{Y}$, who wants to stand out from other consumers (individualisation). According to J. Forsyth, craft coffees are currently enjoying the largest sales in the USA, but within the next few years this trend will spread all over the world. The RTD coffee trend meets the consumer trends such as convenience and multisensory experience, and even the health and nutrition trend. Coffee is becoming sparkling and fruity, coffee is filled with soluble grains, coffee is made with brain octane oil and butter from grass-fed cows, free from toxins. The RTD coffee trend coincides with the "The ice age is coming" trend.

Research by the Mintel Group proves that global investments in chilled coffee ready for consumption has recorded annual increases. Coffee producers want to reach younger consumers who like the taste, refreshment and pleasure of this version of coffee. Cold-brewed coffee helps to give the premium status to the ready-to-eat category, which is quickly growing. The premium status is also important for people who follow the "convenient formats go premium" trend. Consumers of coffee want convenience, but at the same time require good quality. These expectations create the possibility of giving premium status to such concepts as instant coffee, coffee capsules and ready-to-consume drinks.

${ }^{29}$ S. Mokrysz: Consumer preferences and behaviour on the coffee market in Poland. Forum Scientiae Oeconomia, 4(4)/2016, p. 98-106; G. Maciejewski, S. Mokrysz, Ł. Wróblewski: Preferencje konsumentów wobec marek kaw dostępnych na polskim rynku - analiza porównawcza, Marketing i Rynek 4/2018, pp. 35-38.

${ }^{30}$ G. Maciejewski, S. Mokrysz, Ł. Wróblewski: Segmentation of coffee consumers using sustainable values: Cluster analysis on the polish coffee market. Sustainability 11(3, 613)/2019, pp. 11-16; https://doi.org 10.3390/su11030613. 
On the other hand, for coffee consumers who want a change, to have fun and new experiences, coffee makers propose co-branding to dial up indulgence. An example of this is the latte macchiato with a cream liqueur flavour of Tassimo and Bailey's. This product combines the taste of espresso, non-alcoholic cream liqueur and creamy foam.

More and more consumers are paying attention to health issues and are increasingly looking for coffee that provides health benefits ${ }^{31}$. This situation creates the possibility of developing the super coffee trend. For consumers following this trend, organic coffees, caffeine-free coffees, as well as coffee with health-enhancing additives such as proteins, vitamins, chia seeds and coconut oil are being developed ${ }^{32}$. According to research by the Mintel Group, this trend is expected to spread rapidly over the next two years.

Consumer trends of digitalisation, convenience and I want it now! Are converging into the response in the form of "The world of smart vending machines" trend. Over the next five years, it will become the norm to order coffee from vending machines equipped with the "face recognition" function, which can personalise orders. Robots will also replace baristas, all to improve cohesion, reduce costs and shorten waiting times.

The situation on the coffee market is very dynamic and just as some trends will spread, others will weaken or migrate. An example of a migrating trend is coffee capsules (single-serve coffee). The market in the US and western European countries has already been saturated with this type of coffee, but over the next years it has a good chance of spreading to Asia, in particular in China and South Korea.

\section{Conclusion}

Consumer behaviour, in addition to internal determinants, is influenced by numerous external determinants, including megatrends, consumer trends and product trends. The latter ones are the producers' and sellers' response to the changing needs and preferences of consumers. The situation is not different in the coffee market, which is part of a larger food and drink market. Analysing the collected source materials, it can be assumed that, among consumer trends, the ones with the most impact on consumer behaviour on the coffee market will be naturalness and sustainability, health and nutrition as well as multisensory experience and convenience. Digitalisation and individualisation will also be important.

Coffee producers and sellers who want to maintain or strengthen their competitive advantage have to meet these trends - what is more, they have to become active market creators themselves. The response of the supply side to the reported consumer needs will include the development of craft coffees, ready-to-consume hot and cold brewed coffees, coffees that are convenient to prepare and at the same time have a high quality, coffees that improve the health condition of a person, surprise us with new flavours and ingredients used. These trends will gain strength in the near future, i.e. 2021-2024.

\footnotetext{
${ }^{31}$ W.S. Sepúlveda, L. Chekmam, M.T. Maza, N.O. Mancilla: Consumers' preference for the origin and quality attributes associated with production of specialty coffees: Results from a cross-cultural study. Food Research International 89/2016, p. 997-1003.

${ }^{32}$ V. Kumar, J. Kaur, A. Panghal, S. Kaur, V. Handa: Caffeine: a boon or bane. Nutrition \& Food Science 48(1)/2018, p.61-75, https://doi.org/10.1108/NFS-05-2017-0100.
} 


\section{References}

Angus A., Westbrook G: Top 10 global consumer trends 2019, Euromonitor International, London 2018

Borodako K.: Foresight w zarządzaniu strategicznym, C.H. Beck, Warszawa 2009

de Meyer F.: The impact of megatrends on western governments, Institute for Future Insights, Available online: https:/www.slideshare.net/fdemeyer/the-impact-of-megatrends-on-westerngovernments, (accessed on 21 February 2019)

Dimara E., Skuras D.: Consumer demand for informative labeling of quality food and drink products: a European Union case study, Journal of Consumer Marketing 22(2)/2005, https://doi.org/10.1108/07363760510589253

Dybka S.: Trendy w zachowaniach konsumentów jako czynnik determinujący rozwój przedsiębiorstw, Studia Ekonomiczne. Zeszyty Naukowe Uniwersytetu Ekonomicznego w Katowicach 338/2017

Gonzalez-Perez M.A., Gutierrez-Viana s.: Cooperation in coffee markets: The case of Vietnam and Colombia, Journal of Agribusiness in Developing and Emerging Economies 2012/ 2(1)

Hajkowicz S., Moody J.: Our future world. An analysis of global trends, shocks and scenarios, CSIRO, Canberra 2010

Harrison D.: Ten global consumer trends in 2011, Strategic Direction 27(10)/2011, https://doi.org/10.1108/sd.2011.05627jaa.010

Kotler Ph., Armstrong G., Saunders J., Wong V.: Marketing. Podręcznik europejski, PWE, Warszawa 2002

Kotler Ph.: Marketing, Dom Wydawniczy Rebis, Poznań 2005

Kumar V., Kaur J., Panghal A., Kaur S., Handa V.: Caffeine: a boon or bane, Nutrition \& Food Science 48(1)/2018, https://doi.org/10.1108/NFS-05-2017-0100

Maciaszczyk M.: Wybrane megatrendy i ich możliwy wpływ na konsumentów niepełnosprawnych ruchowo, Handel Wewnętrzny, 5(364)/2016

Maciejewski G., Mokrysz S., Wróblewski Ł.: Preferencje konsumentów wobec marek kaw dostępnych na polskim rynku - analiza porównawcza, Marketing i Rynek 4/2018

Maciejewski G., Mokrysz S., Wróblewski Ł: Segmentation of coffee consumers using sustainable values: Cluster analysis on the polish coffee market. Sustainability 11(3, 613)/2019, https://doi.org/10.3390/su1103 0613

Maciejewski G.: The Contemporary Consumer in the Face of Megatrends in Consumption [in:] Olejniczuk-Merta A. (ed.): The Transformation of Consumption and Consumer Behaviour, IBRKK, Warszawa 2012

Marek S., Białasiewicz M. (ed.): Podstawy nauki o organizacji. Przedsiębiorstwo jako organizacja gospodarcza, PWE, Warszawa 2011

Megatrends 2015. Making sense of a world in motion. EYGM Limited 2015

Mokrysz S.: Consumer preferences and behaviour on the coffee market in Poland, Forum Scientiae Oeconomia, 4(4)/2016

Mróz B.: Konsument w globalnej gospodarce. Trzy perspektywy, Oficyna Wydawnicza SGH, Warszawa 2013

Mruk H.: Makrotrendy a zachowania konsumentów [in:] Kędzior Z. (ed.): Konsument. Gospodarstwo domowe. Rynek, CBiE Akademii Ekonomicznej w Katowicach, Katowice 2007

New megatrends will transform the human experience and reshape markets, societies and the global order. EY, Press release, 11 June 2018. Available online: https://www.ey.com/en_gl/news/2018/06/new-megatrends-will-transform-the-human-experienceand-reshape,(accessed on 21 February 2019).

Papista E., Chrysochou P., Krystallis A., Dimitriadis S.: Types of value and cost in consumer green brands relationship and loyalty behaviour, Journal Consumer Behaviour 17/2018 
Penn M.J., Kinney Zalesne E.: Mikrotrendy. Małe siły, które niosą wielkie zmiany, MT Biznes, Warszawa

Pieriegud J.: Wykorzystanie megatrendów do analizy przyszłościowego rozwoju sektorów gospodarki [in:] Gajewski J., Paprocki W., Pieriegud J., Megatrendy i ich wpływ na rozwój sektorów infrastrukturalnych, Instytut Badań nad Gospodarką Rynkową - Gdańska Akademia Bankowa, Gdańsk 2015

Raymond M.: The Trend Forecaster`s Handbook, Laurence King Publishing, London 2014

Sepúlveda W.S., Chekmam L., Maza M.T., Mancilla N.O.: Consumers' preference for the origin and quality attributes associated with production of specialty coffees: Results from a cross-cultural study, Food Research International 89/2016

Shaw F.: Uncertainty and the New Consumer, Foresight 4/2009

Tkaczyk J.: Konsumpcja i konsument - nowe trendy. Handel Wewnętrzny, May - June 2012

Vejlgaard H.: Anatomy of trend, McGraw-Hill, New York 2008

Zalega T.: New consumer trends [in:] Burchard-Dziubińska M. (ed.), Towards a green economy. From ideas to practice, Wydawnictwo Uniwersytetu Łódzkiego, Łódź 2015

Zalega T.: Nowe trendy i makrotrendy w zachowaniach konsumenckich gospodarstw domowych w XXI wieku, Konsumpcja i Rozwój 2(5)/2013

Zmyślony P., Niezgoda A.: Popyt turystyczny. Uwarunkowania i perspektywy rozwoju. Wydawnictwo Akademii Ekonomicznej, Poznań 2003

\section{Nowe trendy w konsumpcji na rynku kawy}

\section{Streszczenie}

Celem artykułu jest przybliżenie trendów w konsumpcji, które oddziaływają obecnie lub będą oddziaływać w perspektywie 2-5 lat na zachowania konsumentów kawy. Artykuł ma charakter teoretycznych rozważań wspartych analizą materiałów źródłowych. Przedstawione w nim zostały główne megatrendy, trendy konsumenckie oraz trendy produktowe obserwowane na rynku kawy. Opisano w nim także relacje zachodzace między wymienionymi zjawiskami a zachowaniami konsumentów. Przeprowadzona analiza zgromadzonych danych pozwoliła stwierdzić, że główne trendy determinujące zachowania konsumentów to naturalność i zrównoważony rozwój, zdrowie $i$ zdrowe odżywianie, wielozmystowe doświadczenia, wygoda, digitalizacja oraz indywidualizacja. Producenci i sprzedawcy kawy wychodząc naprzeciw tym trendom, będą również chcieli sami uzyskać wpływ na wybory i preferencje konsumentów kawy wspierając i rozwijając takie trendy produktowe jak: czas kawy rzemieślniczej, epoka lodowcowa - kawy parzone na zimno, kawy gotowe do spożycia, łaczenie marek dla większej przyjemności, kawa wygodna $w$ formacie premium, czas super kawy czy świat inteligentnych automatów.

Słowa kluczowe: megatrendy, trendy konsumenckie, trendy na rynku żywności i napojów, trendy produktowe, rynek kawy.

JEL Codes: D12, E21, M30 
Information about authors:

Dr hab. Grzegorz Maciejewski, prof. UE

University of Economics in Katowice

Faculty of Economics. Department of Markets and Consumption

ul. 1-go maja 50

40-287 Katowice

e-mail: grzegorz.maciejewski@ue.katowice.pl

ORCID 0000-0002-1318-0747

Mgr Sylwia Mokrysz

Mokate SA

ul. Katowicka 265 a

43-450 Ustroń

e-mail: sylwiamo@gmail.com 